Ekonomia - Wroclaw Economic Review 26/2 (2020)

Acta Universitatis Wratislaviensis

No 3992

https://doi.org/10.19195/2658-1310.26.2.9

Halina Woźniak

ORCID: 0000-0002-1581-0271

Urząd Statystyczny we Wrocławiu

Uniwersytet Ekonomiczny we Wrocławiu

h.wozniak@stat.gov.pl

Elżbieta Stańczyk

ORCID: 0000-0002-6727-7392

Urząd Statystyczny we Wrocławiu

e.stanczyk@stat.gov.pl

\title{
Analiza empiryczna zróżnicowania rezultatów pracy ankieterów w kontekście konstrukcji systemu premiowania
}

Artykuł nadesłany: 9.12.2019; artykuł zaakceptowany: 25.05.2020

Kody klasyfikacji JEL: J33, P43, M5

Keywords: survey quality, data quality, survey completeness index, statistical interviewer, bonus system

\begin{abstract}
Empirical analysis of the diversity of results of interviewers' work in the context of construction of the bonus system

The introduction of an additional financial incentive for statistical interviewers aims to improve the quality of statistical surveys carried out in households as well as the quality of quotation of goods and services conducted in retail outlets and service points, inter alia, by increasing the completeness of these surveys. These are conducted by Statistics Poland and its local agendas, i.e. statistical offices. The aim of the article is to analyse the diversity of results of interviewers' work in the context of construction of the bonus system.

As a measure of the result of the interviewer's work, the survey completeness index was used, which may be the basis for the level of thresholds defining the amount of the bonus.
\end{abstract}


In particular, the aim of the article is to analyse the distribution of the level of completeness index for selected statistical surveys carried out by statistical interviewers and to indicate the studies which should be the components of the construction of the bonus system.

For the purpose of empirical analysis, the results of completeness indices from the four quarters of 2018, obtained by interviewers employed in a selected statistical office, were used. The data refer to four main cyclical surveys carried out by Statistics Poland with the sample method.

\section{Wprowadzenie}

W dzisiejszej, bardzo dynamicznie zmieniającej się rzeczywistości obserwuje się coraz to większe zapotrzebowanie na aktualne i rzetelne informacje statystyczne przydatne do oceny zjawisk społecznych i ekonomicznych. Jednym z podstawowych publicznych, ogólnokrajowych elementów systemu informacyjnego państwa, który zbiera i gromadzi ogromne zasoby danych, jest system statystyki publicznej. Zmieniająca się rzeczywistość oraz potrzeby informacyjne odbiorców danych statystycznych, a także zakres wykorzystania statystyki w różnych dziedzinach stawiają przed statystyką publiczną nowe wyzwania i coraz to wyższe wymagania. Dotyczą one w dużej mierze utrzymania wysokiej jakości badań statystycznych opartych na rzetelnej metodologii.

Niezależnie od stosowanych procedur $\mathrm{w}$ zakresie pozyskiwania danych oraz działań kontrolnych zgodnych z międzynarodowymi standardami mających na celu doskonalenie procesu produkcji statystycznej uzyskanie jak najlepszej jakości danych statystycznych nie jest zadaniem łatwym. Pozyskiwanie danych od respondentów jest często obarczone wieloma problemami, szczególnie danych od respondentów z gospodarstw domowych, w których badania ankietowe prowadzą ankieterzy statystyczni. Badania te, w przeciwieństwie do pozostałych badań statystycznych prowadzonych $\mathrm{w}$ grupie podmiotów gospodarki narodowej, nie są obowiązkowe dla respondenta, co sprawia, że pozyskanie danych wymaga szczególnych kompetencji i umiejętności, nie tylko merytorycznych, ale też społecznych.

Powstaje zatem problem, ciągle aktualny, co poza działaniami standardowymi na rzecz usprawnienia metodyki i organizacji badań można i należy jeszcze zrobić, aby poprawiać ich nie zawsze satysfakcjonującą jakość. Chodzi o działania dodatkowe, poza wystandaryzowaną procedurą na rzecz poprawy jakości badań, odnoszącą się do monitorowania jakości badań jako procesu, opisaną na przykład w Europejskim Kodeksie Praktyk Statystycznych (2017) i zarządzeniu wewnętrznym Prezesa GUS nr 35 z dnia 28 grudnia 2011 roku w sprawie pomiaru, oceny oraz monitorowania jakości badań statystycznych w służbach statystyki publicznej (por. Kompendium wiedzy..., 2012). Jak wpłynąć na poprawę rezultatów pracy ankieterów? Jednym z możliwych do wykorzystania w tym celu instrumentów są bodźce finansowe, które wiązałyby rezultaty pracy ankietera $\mathrm{z}$ odpowiednio do nich dopasowaną określoną gratyfikacją finansową w postaci premii.

Wykorzystanie premii jako bodźca finansowego w celu wzmacniania działań pracowników nie jest typowe w grupie pracowników administracji rządowej, re- 
alizujących jej zadania statutowe. Jednak z powodu szczególnych uwarunkowań prawnych dotyczących ankieterów statystycznych jest to możliwe do zastosowania. Ze względu na złożoność zadań realizowanych przez ankieterów oraz potencjalne zmiany w otoczeniu prawno-organizacyjnym należy problem potraktować szerzej, na gruncie opracowywania metodyki premiowania służącej poprawie jakości badań, której niezbędnym elementem jest ocena rezultatów pracy. Dlatego też głównym punktem zainteresowania autorek tego opracowania jest ocena tych rezultatów.

Badania literaturowe pokazują, że opracowywane w przedsiębiorstwach i instytucjach systemy premiowania mogą być źródłem niezadowolenia pracowników i pracodawców - w szczególności dotyczy to premii uznaniowych (por. na przykład Nelson 1999) ${ }^{1}$. Jedną z przyczyn takiej sytuacji jest między innymi brak powiązania wyników ocen rezultatów pracy pracowników z określonym poziomem premii. Dotyczy to także ankieterów statystycznych.

W artykule jako miarę rezultatu pracy ankietera wykorzystano tak zwany wskaźnik kompletności badania, czyli stosunek liczby ankiet zrealizowanych do liczby ankiet otrzymanych do realizacji, wyrażony w procentach (inaczej: jest to stopień przebadania wylosowanej próby). Wskaźnik ten może być podstawą konstrukcji poziomów systemu premiowania, definiujących wysokość premii. Badania autorów skoncentrowały się na analizie poziomu wskaźnika kompletności dla wybranych statystycznych badań ankietowych (KGD - Kondycja Gospodarstw Domowych, BAEL - Badanie Aktywności Ekonomicznej Ludności, BGD - Budżety Gospodarstw Domowych, C-02 - Badanie cen detalicznych w punktach sprzedaży detalicznej, które zostało wzięte pod uwagę w prowadzonej analizie ze względu na swoje duże znaczenie, mimo że nie jest realizowane w gospodarstwach domowych, lecz w punktach notowania cen, na przykład w sklepach) przeprowadzanych przez ankieterów statystycznych. Badania te, prowadzone w całym kraju przez GUS, realizowane są metodą reprezentacyjną. Do analizy empirycznej wykorzystano dane dotyczące wskaźników kompletności $\mathrm{z}$ badań zrealizowanych przez ankieterów zatrudnionych $\mathrm{w}$ wybranym urzędzie statystycznym w czterech kwartałach 2018 roku.

Celem artykułu jest analiza zróżnicowania rezultatów pracy ankieterów statystycznych w kontekście konstrukcji systemu premiowania. Z jednej strony przedmiotem tej analizy jest charakterystyka rozkładu poziomu wskaźnika kompletności dla wybranych statystycznych badań ankietowych realizowanych przez ankieterów statystycznych, a z drugiej strony — wskazanie badań, które powinny

${ }^{1}$ Por. również źródła internetowe, na przykład badania Sedlak\&Sedlak wśród 18791 pracowników wybranych firm polskich: Systemy premiowe nie zadowalaja pracowników. Gdzie tkwi błąd? (25.09.2018). Data dostępu: 20.10.2019, https://www.pulshr.pl/wynagrodzenia/systemy-premiowe-nie-zadowalaja-pracownikow-gdzie-tkwi-blad,57590.html; lub J. Marciniak, Systemy premiowe - dostosowanie do specyfiki firmy. Data dostępu: 20.10.2019, http://www.lgrant.com/Systemy-premiowe-dostosowanie-do-specyfiki-firmy. 
być elementami konstrukcji systemu premiowania, branymi pod uwagę w szczególności przy opracowywaniu kryteriów premiowania.

\section{Jakość w statystyce publicznej a rezultaty pracy ankieterów}

Jakość w statystyce publicznej jest oparta na definicji jakości Europejskiego Systemu Statystycznego i określona na podstawie sześciu komponentów jakości (por. Kompendium wiedzy..., 2012; Walczak, 2013). Obejmują one:

- przydatność,

— dokładność,

— terminowość i punktualność,

— dostępność i przejrzystość,

- porównywalność,

- spójność.

Zaliczana do komponentów jakości terminowość danych odzwierciedla czas między ich dostępnością a opisywanym wydarzeniem lub zjawiskiem. Punktualność jest to opóźnienie czasowe pomiędzy datą upowszechnienia danych a planowaną datą dostarczenia danych, wynikającą z dat ogłaszanych w oficjalnym kalendarzu publikacji, ustanowionych w zarządzeniach lub uzgodnionych wcześniej między partnerami ${ }^{2}$.

$\mathrm{Na}$ gruncie polskiego prawa zagadnienia jakości badań statystycznych są zawarte w ustawie o statystyce publicznej w art. 25a (Dz.U. z 2019 r. poz. 649). Dodatkowo w obszarze statystyki publicznej istnieje wiele dokumentów regulujących szczegółowo to zagadnienie. Najistotniejszym z nich jest zarządzenie wewnętrzne Prezesa GUS nr 35 z 28 grudnia 2011 r. w sprawie pomiaru, oceny i monitorowania jakości badań statystycznych ${ }^{3}$. GUS korzysta także z dobrych praktyk i zaleceń w tym zakresie, przygotowywanych przez ekspertów międzynarodowych, między innymi z Eurostatu.

Analiza jakości danych statystycznych w zakresie ich dokładności (precyzji) w statystyce publicznej polega na analizie błędów losowych (błędów próby) i nielosowych (błędów niezwiązanych z próbą). W szczególności do błędów niezwiązanych z próbą zalicza się:

2 Definicje jakości przyjęte w statystyce publicznej są opracowywane na podstawie dokumentu Eurostat 4.2. - dokumenty metodologiczne - definicja jakości w statystyce dla potrzeb grupy roboczej „Ocena jakości w statystyce”, spotkanie szóste, Luksemburg, 2-3 października 2003. Data dostępu: 20.02.2020, https://bip.stat.gov.pl/dzialalnosc-statystyki-publicznej/jakosc-w-statystyce/ definicja-jakosci-w-statystyce-publicznej/.

3 https://bip.stat.gov.pl/dzialalnosc-statystyki-publicznej/jakosc-w-statystyce/ocena-i-monitorowanie-jakosci-procesow-statystycznych/ (dostęp: 20.02.2020).

Ekonomia - Wroclaw Economic Review 26/, 2020

(C) for this edition by CNS 
— błędy pomiaru — są to błędy, które pojawiają się podczas gromadzenia danych i powodują, że zebrane wartości zmiennych mogą różnić się od wartości rzeczywistych;

- błędy przetwarzania - powstają na etapie pomiędzy gromadzeniem danych a rozpoczęciem analizy statystycznej, kiedy dane zostają poddane określonemu przetworzeniu: wprowadzaniu, kodowaniu, redakcji, imputacji itp.;

— błędy braku odpowiedzi:

— brak odpowiedzi jednostki podmiotowy — gdy jednostka nie złożyła sprawozdania lub nie udzieliła wywiadu;

— brak odpowiedzi przedmiotowy — na dany punkt formularza/ankiety (por. Kompendium wiedzy..., 2012).

Podstawowym zadaniem ankietera statystycznego jest realizacja badań w losowo wybranych gospodarstwach domowych, sprawne przeprowadzenie wywiadu oraz zebranie kompletnych i rzetelnych informacji. Takie same wymagania powinny zostać spełnione w przypadku badania cen, które jest realizowane w punktach sprzedaży detalicznej. Praca w terenie dotycząca realizacji badań ankietowych jest pracą wymagającą wielu kompetencji, nie tylko merytorycznych, ale też społecznych, które ankieterzy muszą umiejętnie wykorzystywać, aby powierzone zadania wykonać jak najlepiej i pokonać wiele trudności związanych z pozyskaniem danych od respondentów. Są one związane nie tylko ze złożoną metodyką badań statystycznych, czasochłonnością ankietowania, koniecznością dostosowywania się do zmieniających się narzędzi ankietowania (zmieniające się aplikacje stosowane w metodzie pozyskiwania danych CAPI, czyli metodzie pozyskiwania danych $\mathrm{w}$ postaci wywiadu bezpośredniego $\mathrm{z}$ respondentem wspomaganego aplikacją na urządzeniu mobilnym), ale też z problemami dotyczącymi niemożności nawiązania kontaktu z respondentem lub wręcz z odmową odpowiedzi na pytania zawarte w ankiecie. W tych złożonych warunkach realizacji badań ankietowych zdarzają się również błędy popełniane przez samych ankieterów. Dlatego rezultaty pracy ankieterów statystycznych są kluczowymi determinantami jakości badań statystycznych.

\section{Rezultaty pracy ankietera a system premiowania}

Jednym z możliwych do wykorzystania instrumentów poza dotychczas stosowanymi procedurami organizacyjnymi i kontrolnymi mających na celu poprawę jakości badań statystycznych są bodźce finansowe, które wiązałyby rezultaty pracy ankietera $\mathrm{z}$ odpowiednio określoną gratyfikacją finansową w postaci premii. W szczególności premiowanie sformalizowane charakteryzuje się ścisłym uzależnieniem wysokości premii od realizacji zadań premiowych. Stosowanie tego rodzaju premiowania opiera się na zasadzie uruchamiania premii w sytuacji, gdy pracownik (lub zespół pracowniczy) wykonał określone zadania premiowane 
na wymaganym poziomie ilościowym i jakościowym. Ten sposób premiowego wzmacniania działań pracowników ze względu na szczególne unormowanie prawne dotyczące ankieterów statystycznych jako pracowników administracji rządowej jest możliwy do zastosowania ${ }^{4}$.

Projektując systemy premiowe, należy wziąć pod uwagę:

- zdefiniowanie zadań premiowych,

— zdefiniowanie kryteriów oceny rezultatów pracy (stopnia realizacji zadań premiowych),

— zdefiniowanie zasad przeniesienia oceny rezultatów pracy na określony poziom premii.

Jak podkreśla się w wielu opracowaniach (por. między innymi Gruszczyńska-Malec, 2008; Kopertyńska, 2000; Mikrut, Tomasiewicz, 2009), system premiowania musi być jasny i zrozumiały (między innymi ankieter powinien móc samodzielnie wyliczyć przewidywaną premię).

Do głównych założeń systemu premiowania zalicza się następujące aspekty:

- premiowane powinny być tylko wybrane priorytety (wybrane badania);

- premiowanie według kryteriów zależnych od ankietera;

— premiowanie wedługg zasad i kryteriów możliwych do osiągnięcia;

— mierzalne kryteria premiowania;

— walor motywacyjny.

Jak ważny jest walor motywacyjny oraz odpowiednie procedury przy premiowaniu, zwracają uwagę między innymi Sirota, Mischkind, Meltzer (2006) oraz Osabiya (2015). Natomiast w świetle swoich badań empirycznych Joo i Gottfredson (2013) podkreślają ogólne zasady, które pomagają w opracowaniu skutecznych systemów wynagrodzeń pieniężnych, próbując ocenić, kiedy i dlaczego systemy nagród pieniężnych mogą odnieść sukces pod względem poprawy motywacji i wydajności pracowników. Na przykładzie ankieterów telefonicznych zagadnienia dotyczące wpływu grupowych i indywidualnych zachęt finansowych na produktywność pracowników poruszali w swoich analizach Thurkow, Bailey i Stamper (2000). Ocenę wpływu bodźców finansowych na motywację pracowników, w szczególności na wydajność pracy na przykładzie wybranej jednej z firm z siedzibą na Ukrainie, przedstawia publikacja Mokhniuk (2016). Interesującą próbę przeglądu wymienianych w literaturze przedmiotu teorii, modeli teoretycznych dotyczących wpływu zachęt pieniężnych na efekt wykonania przez pracowników powierzonych zadań zawarto w pracy Bonner i Sprinkle (2002).

Nie odnaleziono natomiast żadnych uznanych źródeł literaturowych, które odnosilyby się wprost do systemów motywowania ankieterów, tym bardziej ankieterów wykonujących zadania na rzecz statystyki publicznej. Obecnie urzędy statystyczne oceniają ankieterów poprzez przypisane im mierniki (liczba i ro-

${ }^{4}$ Rozporządzenie Rady Ministrów z dnia 28 marca 2000 r. w sprawie zasad wynagradzania pracowników niebędących członkami korpusu służby cywilnej zatrudnionych w urzędach administracji rządowej i pracowników innych jednostek (Dz.U. Nr 14, poz. 299 z późn. zm.)

Ekonomia - Wroclaw Economic Review 26/, 2020

(C) for this edition by CNS 
dzaj błędów - błędy pomiaru, przetwarzania, braku odpowiedzi podmiotowej i przedmiotowej, dotrzymywanie założonych terminów wykonania zadań, stopień zrealizowania badanej próby). Dokonywane jest to jednak w sposób zróżnicowany, gdyż nie ma jednolitego, systemowego podejścia do tego problemu. Brakuje metodyki określania rezultatów pracy ankietera, toteż brakuje możliwości powiązania jasno określonych kryteriów premiowania z osiągniętymi przez ankietera rezultatami. I właśnie $\mathrm{w}$ kontekście opracowania metodyki systemu premiowania poddano w niniejszym opracowaniu analizie empirycznej rezultaty pracy ankieterów.

Rezultaty pracy ankieterów mogą być określane poprzez wykorzystanie niektórych parametrów służących do ogólnej oceny jakości badań statystycznych, które ankieterzy realizują. Są to przede wszystkim takie elementy, jak: terminowość wykonania powierzonych zadań, dokładność (liczba błędów w ankiecie) oraz kompletność, czyli liczba zrealizowanych ankiet w odniesieniu do liczby ankiet powierzonych ankieterowi. W praktyce stosuje się różne zasady oceny rezultatów pracy ankieterów z zastosowaniem tych parametrów. Nie ma jednak standardowego metodycznego podejścia do określania rezultatów pracy ankieterów ani też metodycznego ustandaryzowanego sposobu powiązania rezultatów pracy ankietera z jakością badań statystycznych i systemem premiowania.

\section{Charakterystyka zbioru danych i metod analizy}

W celu oceny poziomu zróżnicowania rezultatów pracy ankieterów w kontekście konstrukcji finansowych poziomów premiowania dokonano analizy surowych danych empirycznych.

Problemem badawczym, który został podjęty na podstwie zebranego materiału empirycznego, było sprawdzenie, czy klasyczne parametry statystyczne mogą być pomocne do wyznaczenia poziomów premiowania.

Podmiotem analizy danych empirycznych była wybrana na podstawie doboru celowego lokalna sieć ankieterów statystycznych, która obejmowała zbiorowość 72 ankieterów - pracowników statystyki publicznej zatrudnionych w ramach umowy o pracę na stanowisku ankietera w 2018 roku w jednym z urzędów statystycznych. Do podstawowych zadań wymienionej grupy ankieterów należało sprawne przeprowadzenie bezpośredniego wywiadu oraz zebranie kompletnych i rzetelnych informacji w ramach realizacji badań w cyklicznie losowanych gospodarstwach domowych. Do badań tych należały wymienione wcześniej badania reprezentacyjne: KGD - Kondycja Gospodarstw Domowych (postawy konsumentów), BAEL - Badanie Aktywności Ekonomicznej Ludności, BGD - Budżety Gospodarstw Domowych oraz C-02 - Badanie cen detalicznych w punktach sprzedaży detalicznej dokonywane na podstawie obowiązującej listy reprezentantów towarów i usług. Badania te są najważniejszymi stałymi bada- 
niami ankietowymi ujmowanymi corocznie w Programie Badań Statystycznych Statystyki Publicznej.

Przedmiotem analizy danych były miary rezultatu pracy ankieterów (dokładność, terminowość i kompletność) przy realizacji wymienionych czterech typów statystycznych badań w każdym kwartale 2018 roku. Na potrzeby niniejszego artykułu w zakresie oceny dokładności przy realizacji badań zastosowano skalę dwuwartościową:

- dla badań BAEL, BGD i KGD:

1 - ankiety zrealizowane poprawnie, nie ma błędów w ankietach lub pojedyncze błędy w ankietach, maksymalnie do $10 \%$ błędów w ankietach;

0 - pozostałe przypadki (w tym między innymi formularze nieczytelne, w całości nadające się do weryfikacji);

— dla badania C-02 w odniesieniu do zanotowanych reprezentantów w cenach:

1 - ceny zanotowane poprawnie po kilka błędów w zakresie pojedynczego sprawozdania, maksymalnie do 80 sztuk błędów w kwartale;

0 - pozostałe przypadki ( $w$ tym między innymi formularze nieczytelne, w całości nadające się do weryfikacji).

W zakresie oceny terminow ości przy realizacji każdego z wymienionych typów badań zastosowano również skalę dwuwartościową:

1 — nie ma spóźnień według ustalonych harmonogramów, ewentualnie jedno spóźnienie,

0 - pozostałe przypadki.

Wskaźnik kompletności badania (stopień przebadania wylosowanej próby), który wyraża stosunek liczby ankiet zrealizowanych do liczby ankiet otrzymanych do realizacji, przeliczony w procentach (inaczej: jest to stopień przebadania wylosowanej próby) przyjmuje wartość z przedziału [0,100\%]. Przy realizacji założonych celów badawczych poza metodą analizy i krytyki literatury przedmiotu skorzystano głównie z metod statystycznej analizy danych. Aby ocenić poziom zróżnicowania tych wskaźników pomiędzy poszczególnymi badaniami i przeanalizować rozkłady empiryczne, w tym asymetrię, obliczono klasyczne parametry statystyczne (w tym wskaźnik skośności i kurtozę) oraz wskaźnik podobieństwa struktur Bray'a-Curtisa (Bray, Curtis, 1957; Ostasiewicz, 2011) dla danych par typów badań zgodnie z wzorem:

$$
w_{s}=\sum_{i=1}^{k} \min \left\{w_{1 i} \mid w_{2 i}\right\},
$$

gdzie $k$ - liczba klas (przyjęto 10 klas poziomu kompletności o jednakowych rozpiętościach wynoszących 10 p.proc.), $w_{l i}$ oraz $w_{2 i}$ - udziały procentowe ankieterów osiągających poziom kompletności z $i$-tej klasy, odpowiednio w obu typach badania. 
Dodatkowo, aby sprawdzić występowanie związku korelacyjnego, skorzystano z nieparametrycznego współczynnika korelacji rang Spearmana dla danych dotyczących kompletności wybranych badań (Ostasiewicz, 2011):

$$
r_{s}=1-\frac{6 \sum_{i=1}^{n} d_{i}^{2}}{n\left(n^{2}-1\right)}
$$

gdzie $d_{i}$ - różnice między rangami odpowiadających sobie wartości cech (kompletności wybranych badań).

Do oceny siły oraz kierunku asymetrii zastosowano współczynnik skośności (asymetrii) określający, jaką część odchylenia standardowego (s) stanowi różnica pomiędzy średnią arytmetyczną a medianą — tak zwany drugi współczynnik skośności Pearsona (Kędelski, Roeske-Słomka, 1997):

$$
w_{A}=3 \frac{\bar{x}-M e}{s} .
$$

Obliczenia wykonano, korzystając z pakietu Statistica.

\section{Wyniki analizy rezultatów pracy wybranej zbiorowości ankieterów}

Pierwszym etapem analizy rezultatów pracy ankieterów przy wyborze przykładowego jednego roku pracy (2018) było obliczenie parametrów klasycznych statystyki opisowej cech oznaczających kompletności wybranych badań ankietowych, czyli BGD, KGD, BAEL i C-02 (por. tabela 1). Wyniki te zostały zilustrowane graficznie w formie wykresów pudełkowych (por. wykres 2). Wysoką kompletnością charakteryzowało się badanie cen detalicznych C-02 (89,7\%), natomiast pozostałe, w których podmiotem badania jest gospodarstwo domowe, nie osiągały poziomu $50 \%$, w tym najniższą kompletność miało najbardziej pracochłonne badanie budżetów gospodarstw domowych (42,2\%).

$\mathrm{Z}$ uwagi na brak danych odstających dla cech określających kompletności wszystkich omawianych badań parametry klasyczne są właściwe do oceny tych cech statystycznych.

Najwyższe wartości współczynnika zmienności odnotowano w przypadku badań BGD i KGD (zmienność na poziomie 46,5\% i 44,0\%). Z uwagi na to duże zróżnicowanie kompletności wśród ankieterów, które umożliwia wyznaczenie w sposób przejrzysty poziomów premii oraz wskazuje na konieczność podjęcia działań motywujących w zakresie podniesienia kompletności tego badania wśród pracowników osiągających najniższe rezultaty, badania BGD i KGD powinny zostać włączone do konstrukcji systemu premiowania.

W badaniach BGD, KGD i BAEL większość ankieterów osiągała wyniki kompletności badania mniejsze od średniej, co z kolei oznacza potrzebę oddziaływa- 
nia motywującego na ten obszar działań ankieterów. W szczególności podmiotem wsparcia motywującego powinna być grupa ankieterów osiągająca w badaniach bardzo niską kompletność. Poniżej progu: średnia kompletność minus odchylenie standardowe, odnotowano, odpowiednio, dla badania BGD - 14,5\% takich przypadków, dla KGD - 11,1\%, dla BAEL - 15,7\%, a dla C-02 - 17,6\% (por. wykres 2).

Premia nagradzająca za uzyskanie wysokiej kompletności badań ankietowych może sprawić, że uzyskane przez ankieterów wysokie kompletności badań spowodują, że kompletność będzie miała asymetrię lewostronną.

W świetle wybranych do analizy danych empirycznych tylko kompletność zrealizowanego przez ankieterów badania C-02 charakteryzowała się asymetrią lewostronną. Największą asymetrię prawostronną otrzymano dla kompletności badania BGD i KGD. Osiągnięcie asymetrii lewostronnej byłoby korzystne zarówno dla pracodawcy, jak i ankieterów. Oznacza to bowiem, że większość ankieterów uzyskałaby wyniki kompletności wyższe niż średnia kompletność w tej grupie (por. wykres 2).

Łącznie odsetek ankieterów osiągających akceptowalny poziom zarówno dokładności realizacji ankiet, jak i terminowości (oba komponenty jakości z oceną , "1”) wynosił w przypadku badania BAEL - 70,1\%, BGD - 75,5\% oraz KGD $-76,2 \%$.

Jednocześnie, biorąc pod uwagę ocenę dokładności realizacji ankiet, stwierdzono, że w każdym z wymienionych trzech typów badań w zbiorowości ankieterów, w której osiągano kompletność co najmniej na poziomie średniej, odsetek ankieterów o akceptowalnej dokładności był wyższy niż w drugiej zbiorowości ankieterów (o poziomie kompletności poniżej wartości średniej). Odsetek pracowników o akceptowalnej dokładności (przypisanej ocenie „1”) wynosił w badaniu:

— BAEL - 92,9\% wśród ankieterów osiągających kompletność na poziomie co najmniej średniej (wobec $85,1 \%$ wśród ankieterów osiągających kompletności poniżej średniej);

- BGD - 87,8\% (wobec 87,3\%);

- KGD - 94,3\% (wobec 88,6\%).

Nieznacznie większe dysproporcje kształtowały się w odsetkach pracowników o akceptowalnej terminowości (przypisanej ocenie „1”), mianowicie wynosiły one w badaniu:

— BAEL — 90,6\% wśród ankieterów osiągających kompletność na poziomie co najmniej średniej (wobec 73,1\% wśród ankieterów osiągających kompletność poniżej średniej);

- BGD - 81,1\% (wobec 75,5\%);

- KGD - 94,3\% (wobec 88,6\%).

Lepsze wyniki w zakresie kompletności znajdowały zatem odzwierciedlenie w lepszych wynikach w zakresie pozostałych komponentów jakości badań, to jest dokładności i terminowości.

Badanie cen detalicznych C-02 wyróżniało się na tle pozostałych badań oprócz największej średniej kompletności także niewielkim zróżnicowaniem - 
nieistotnym statystycznie. Ze względu na to, że — odmiennie niż w pozostałych badaniach — dla podmiotu przekazującego dane (punktów sprzedaży detalicznej) jest ono badaniem obowiązkowym (w przypadku gospodarstw domowych przekazywanie informacji ma charakter dobrowolny) oraz z uwagi na sposób pozyskiwania informacji (notowanie cen, a nie wywiady) badanie cen detalicznych C-02 wymaga istotnie mniejszego zaangażowania i nakładu pracy ankietera.

Tabela 1. Podstawowe parametry statystyczne dla cech określających kompletność wybranych badań w 2018 roku

\begin{tabular}{|l|c|c|c|c|}
\hline \multirow{2}{*}{ Wyszczególnienie } & \multicolumn{4}{c|}{ Badanie } \\
\cline { 2 - 5 } & BGD & BAEL & KGD & C-02 \\
\hline średnia arytmetyczna & 42,2 & 48,3 & 43,9 & 89,7 \\
\hline $\begin{array}{l}\text { odsetek ankieterów osiągających kompletność } \\
\text { na poziomie co najmniej średniej }\end{array}$ & $42,0 \%$ & $48,7 \%$ & $46,9 \%$ & $57,4 \%$ \\
\hline mediana & 39,6 & 48,2 & 41,7 & 90,0 \\
\hline modalna & 54,6 & 50,0 & 50,0 & 92,9 \\
\hline odchylenie standardowe & 19,6 & 17,3 & 19,3 & 3,1 \\
\hline zmienność & $46,5 \%$ & $35,9 \%$ & $44,0 \%$ & $3,4 \%$ \\
\hline skośność (asymetria) & 0,38 & 0,03 & 0,34 & $-0,25$ \\
\hline minimum & 6,9 & 7,2 & 0,0 & 81,6 \\
\hline maksimum & 100,0 & 93,5 & 91,7 & 95,8 \\
\hline
\end{tabular}

Źródło: obliczenia własne.

Obliczone wskaźniki podobieństwa struktur wskazują, że dane dotyczące kompletności badań BAEL i KGD są najbardziej podobne (a także BGD i KGD), co może sugerować, że do konstrukcji systemu premiowania wystarczy uwzględnić tylko wyniki jednego z tych badań w celu uproszczenia i większej czytelności systemu premiowania (por. tabela 2 oraz wykres 1). To przypuszczenie należy jednak potwierdzić jeszcze oceną korelacji danych kompletności z tych badań.

Tabela 2. Wskaźniki podobieństwa struktur dla cech określających kompletność wybranych badań w 2018 roku

\begin{tabular}{|l|c|c|c|c|}
\hline Wyszczególnienie & BGD & BAEL & KGD & C-02 \\
\hline BGD & 1,00 & 0,80 & 0,81 & 0,03 \\
\hline BAEL & 0,80 & 1,00 & 0,85 & 0,05 \\
\hline KGD & 0,81 & 0,85 & 1,00 & 0,03 \\
\hline C-02 & 0,03 & 0,05 & 0,03 & 1,00 \\
\hline
\end{tabular}

Źródło: obliczenia własne. 
Wyniki zawarte w tabeli 3 wskazują, że istotnie skorelowane są dane dotyczące kompletności KGD i BAEL, co potwierdzały wyniki w zakresie podobieństwa struktur, jednak wskaźnik ten, mimo że jest istotny statystycznie, ma niską wartość. Natomiast nie ma zgodności rang (brak skorelowania) odnotowano między badaniem cen C-02 a badaniami BAEL i KGD. Z uwagi na specyfikę organizacji podziału badań między ankieterami w wybranym do badania urzędzie statystycznym, polegającą na niełączeniu u jednego ankietera badania BGD z C-02, nie można policzyć wartości współczynnika korelacji dla tej pary badań.

$\mathrm{Na}$ szarym tle zaznaczono współczynniki wskazujące na istotną zależność (przy przyjęciu poziomu istotności 0,05).

Tabela 3. Współczynniki korelacji rang Spearmana dla cech określających kompletność wybranych badańa w 2018 roku

\begin{tabular}{|l|c|c|c|c|}
\hline Wyszczególnienie & BGD & BAEL & KGD & C-02 \\
\hline BGD & 1,00 & 0,35 & 0,32 & - \\
\hline BAEL & 0,35 & 1,00 & 0,42 & 0,09 \\
\hline KGD & 0,32 & 0,42 & 1,00 & 0,02 \\
\hline C-02 & - & 0,09 & 0,02 & 1,00 \\
\hline
\end{tabular}

Źródło: obliczenia własne.
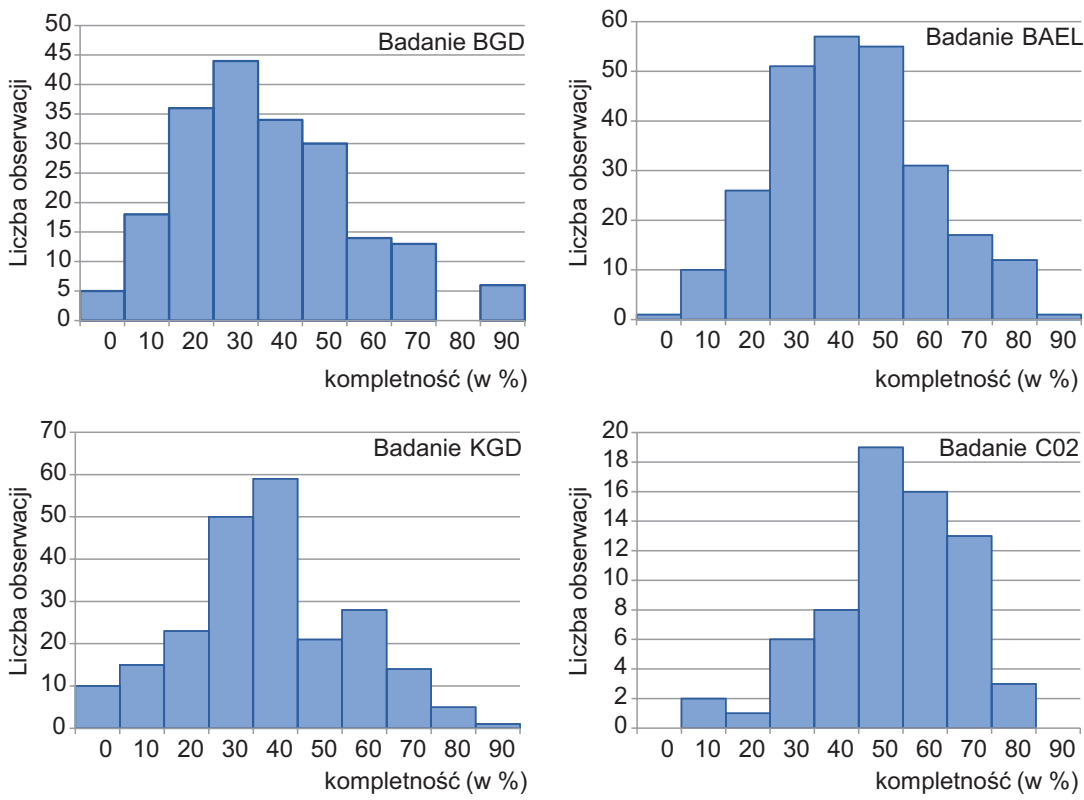

Wykres 1. Rozkład kompletności badań ankietowych zrealizowanych w 2018 roku według wybranych typów badań (dane surowe)

Źródło: opracowanie własne. 
Słupki na wykresie 1 ilustrują liczebności zaobserwowane.

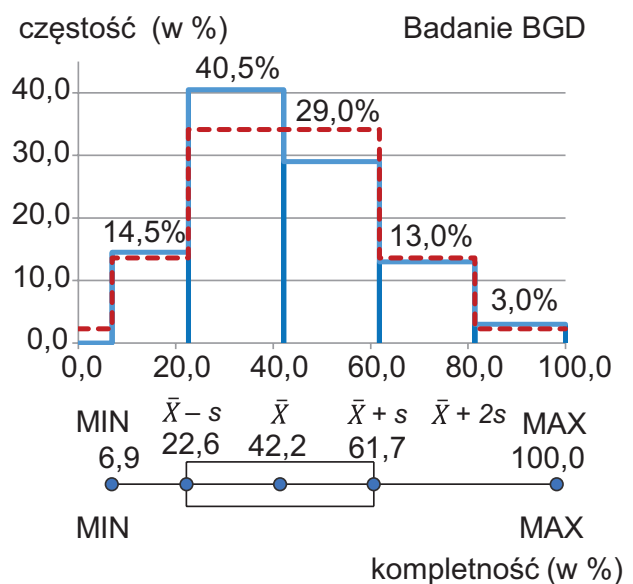

częstość (w \%) Badanie BAEL

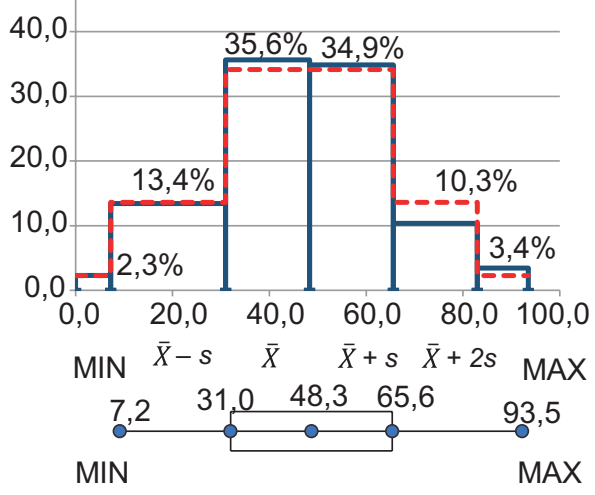

częstość ( $w$ \%)

Badanie KGD

częstość (w \%)

Badanie C-02
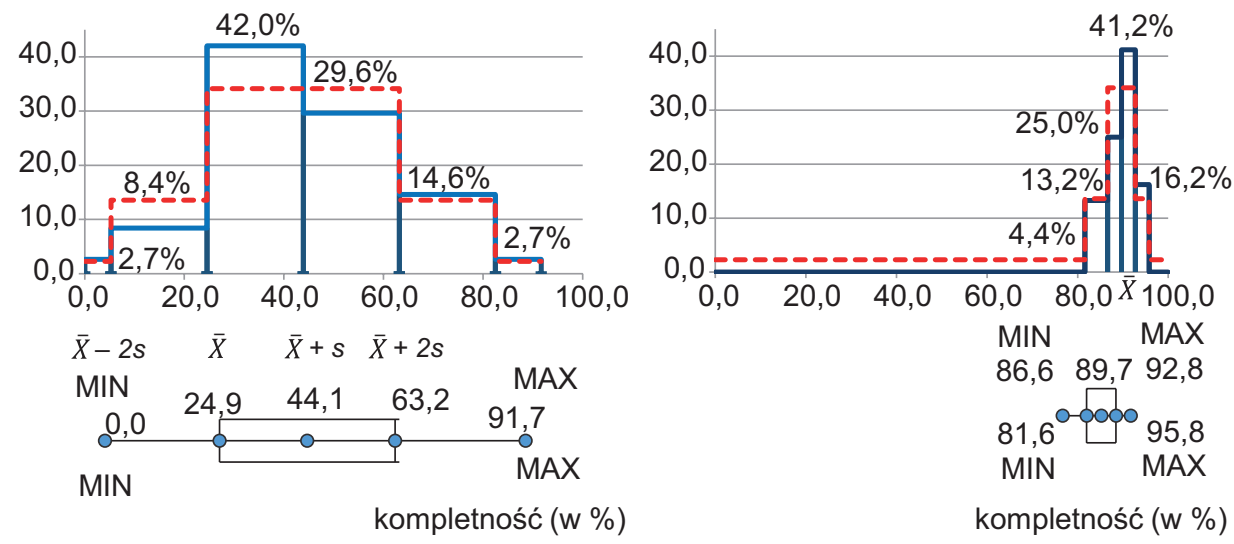

kompletność (W \%)

Wykres 2. Rozkład kompletności badań ankietowych zrealizowanych w 2018 roku według wybranych typów badań oraz wartości średniej (dane surowe)

Źródło: opracowanie własne.

Słupki na wykresie 2 ilustrują częstości zaobserwowane w przedziałach wyznaczonych przez średnią i odchylenie standardowe, natomiast linia czerwona oczekiwane częstości rozkładu normalnego o takiej samej średniej i odchyleniu standardowym.

\section{Wnioski}

Analizując wybrany materiał empiryczny zawierający rezultaty pracy 72 ankieterów statystycznych w zakresie wskazanych czterech cyklicznie realizowanych 
przez GUS badań reprezentacyjnych, stwierdzono odmienność rozkładu ocen jakości badania cen C-02 od pozostałych badań ankietowych. Ze względu na brak obserwacji odstających w rozkładach wskaźnika kompletności oraz na odpowiedni poziom zróżnicowania zaproponowano, aby system premiowania zbudować na ocenie kompletności wszystkich podlegających ocenie nieobowiązkowych badaniach ankietowych, to jest BGD, KGD oraz BAEL, z wykorzystaniem statystycznych parametrów klasycznych.

Ze względu na wymogi w stosunku do procesu realizacji badania i jego jakości (por. rozdział 2) autorzy uważają, że warunkiem koniecznym otrzymania premii powinno być uzyskanie przez ankieterów odpowiedniego poziomu dokładności i terminowości przydzielonych prac (realizacji zadań ankietowych). W szczególności uzyskanie przez ankietera nawet jednej najniższej oceny (,0”) pod względem dokładności lub terminowości powinno uniemożliwić otrzymanie premii. Wyniki analiz wykazały, że lepsze wyniki w zakresie kompletności znajdowały odzwierciedlenie w lepszych wynikach w zakresie pozostałych komponentów jakości badań, to jest dokładności i terminowości. Natomiast możliwość przyznania premii oraz jej wysokość powinny być powiązane z kompletnością ankiet zrealizowanych przez ankietera. Premia za uzyskanie wysokiej kompletności badań ankietowych może spowodować, że rozkład kompletności będzie charakteryzował się asymetrią lewostronną, co jest korzystne zarówno dla pracodawcy, jak i ankieterów, oznacza bowiem, że większość ankieterów uzyska wyniki kompletności wyższe niż średnia kompletność w tej grupie. Efektem wprowadzenia premii nagradzającej uzyskanie wysokiej kompletności badań ankietowych może być poprawa jakości badań statystycznych poprzez wzrost udziału ankieterów osiągających wyniki kompletności wyższe niż średnia kompletność w tej grupie. Aby dokonać jednoznacznej oceny efektów wdrażania poziomów premii, niezbędne są dalsze badania porównawcze.

W wyniku przeprowadzonej analizy empirycznej możliwe stało się uzasadnienie wyboru kryteriów oceny rezultatów pracy ankieterów statystycznych oraz wskazanie na wybrane badania, które powinny zostać wzięte pod uwagę przy projektowaniu systemu premiowego.

\section{Bibliografia}

Bonner, S., Sprinkle, G. (2002). The Effects of Monetary Incentives on Effort and Task Performance: Theories, Evidence, and a Framework for Research. Accounting. Organizations and Society, 27, 303-345. 10.1016/S0361-3682(01)00052-6.

Bray, J.R., Curtis, J.T. (1957). An ordination of upland forest communities of southern Wisconsin. Ecological Monographs, 27, 325-349. Data dostępu: 10.02.2020, https://esajournals.onlinelibrary.wiley.com/doi/10.2307/1942268.

Europejski Kodeks Praktyk Statystycznych dla krajowych organów statystycznych i Eurostatu (organu statystycznego UE) (2017). Komitet ds. Europejskiego Systemu Statystycznego, 
Eurostat. Data dostępu: 14.01.2019, https://bip.stat.gov.pl/files/gfx/bip/pl/defaultstronaopisowa/667/1/1/europejski_kodeks_praktyk_statystycznych_2.pdf.

Gruszczyńska-Malec, G. (2008). Tworzenie systemu płac w przedsiębiorstwie. Warszawa: Wydawnictwo Biblioteczka Pracownika.

Joo, H., Gottfredson, R. (2013). What monetary rewards can and cannot do: How to show employees the money. Business Horizons, 56, 241-249. 10.1016/j.bushor.2012.11.007.

Kędelski, M., Roeske-Słomka, I. (1997). Statystyka. Poznań: Wydawnictwo Akademii Ekonomicznej. Kompendium wiedzy z jakości w statystyce publicznej (2012). Urząd Statystyczny w Łodzi, Ośrodek Statystyki Matematyczne. Departament Metodologii, Standardów i Rejestrów GUS. Warszawa. Data dostępu: 14.01.2019, https://bip.stat.gov.pl/files/gfx/bip/pl/defaultstronaopisowa/668/1/1/kompendium_zew.pdf.

Kopertyńska, W.M. (2000). System płac w przedsiębiorstwie. Wrocław: Wydawnictwo Akademii Ekonomicznej.

Mokhniuk, A.M. (2016). The Impact of Monetary Rewards on the Motivation of Employees. Roczniki Ekonomiczne Kujawsko-Pomorskiej Szkoły Wyższej w Bydgoszczy, 9, 336-346.

Mikrut, A., Tomasiewicz, R. (2009). Wpływ systemu premiowania na wzrost wydajności. Zeszyty Naukowe WSEI. Seria Ekonomia, 1, 177-190.

Nelson, B. (1999). The Ten Ironies of Motivation. Strategy \& Leadership, 27, 1, 26-31. Data dostępu: 20.02.2020, http://www.workforce.com/1999/02/01/the-ten-ironies-of-motivation/; https://doi. org/10.1108/eb054627.

Osabiya, B.J. (2015). The effect of employees' motivation on organizational performance. Journal of Public Administration and Policy Research. Data dostępu: 5.02.2020, http://www.academicjournals.org/article/article1433502383_Osabiya.pdf.

Ostasiewicz, W. (2011). Badania statystyczne. Warszawa: Wolters Kluwer.

Sirota, D., Mischkind, L.A., Meltzer, M.I. (2006). Why Your Employees Are Losing Motivation. Harvard Business School. Working Knowledge, April 10th. Data dostępu: 5.02.2020, http:// hbswk.hbs.edu/archive/5289.html.

Thurkow, N., Bailey, J., Stamper, M. (2000). The Effects of Group and Individual Monetary Incentives on Productivity of Telephone Interviewers. Journal of Organizational Behavior Management, 20, 3-25. 10.1300/J075v20n02_02.

Walczak, T. (2013). Podstawowe standardy jakości statystyki publicznej. Data dostępu: 14.01.2019, http://stat.gov.pl/cps/rde/xbcr/gus/POZ_podstaw_stand_jakosci_statyst_publicz.pdf.

Ekonomia - Wroclaw Economic Review 26/, 2020

(C) for this edition by CNS 